Provided for non-commercial research and education use. Not for reproduction, distribution or commercial use.

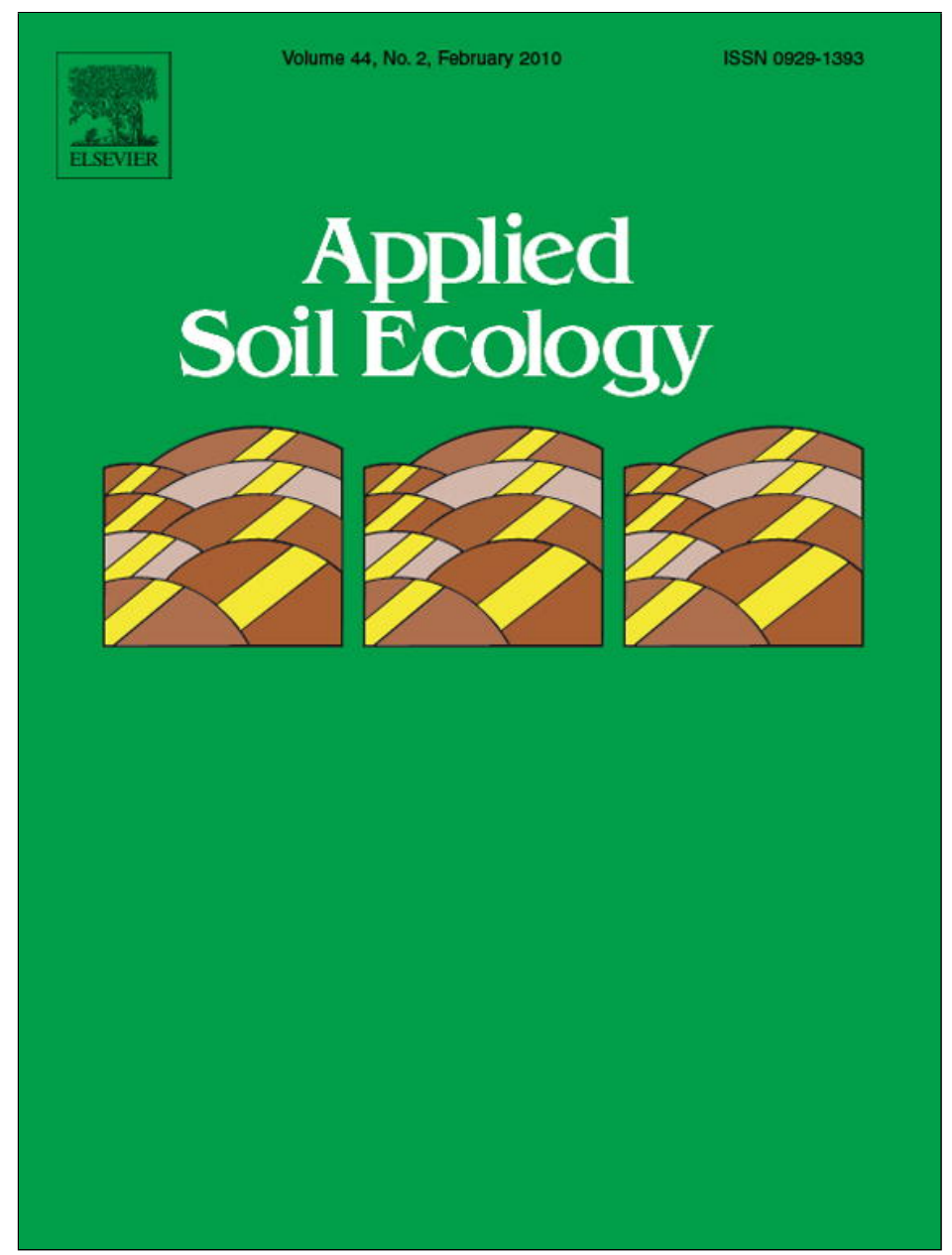

This article appeared in a journal published by Elsevier. The attached copy is furnished to the author for internal non-commercial research and education use, including for instruction at the authors institution and sharing with colleagues.

Other uses, including reproduction and distribution, or selling or licensing copies, or posting to personal, institutional or third party websites are prohibited.

In most cases authors are permitted to post their version of the article (e.g. in Word or Tex form) to their personal website or institutional repository. Authors requiring further information regarding Elsevier's archiving and manuscript policies are encouraged to visit:

http://www.elsevier.com/copyright 


\title{
Comparison of organic and conventional stockless arable systems: A multidisciplinary approach to soil quality evaluation
}

\author{
M. Mazzoncini ${ }^{\text {a }}$, S. Canali ${ }^{\text {b,* }}$, M. Giovannetti ${ }^{\text {c }}$, M. Castagnoli $^{\text {d }}$, F. Tittarelli $^{\text {b }}$, D. Antichi ${ }^{\text {e }}$, \\ R. Nannelli ${ }^{\mathrm{d}}$, C. Cristani $^{\mathrm{c}}$, P. Bàrberi ${ }^{\mathrm{e}}$ \\ a Dipartimento di Agronomia e Gestione dell'Agroecosistema, Università di Pisa, Via S. Michele degli Scalzi 2, 56124 Pisa, Italy \\ ${ }^{\mathrm{b}}$ Centro per lo studio delle relazioni tra pianta e suolo, Consiglio per la ricerca e la sperimentazione in Agricoltura (CRA-RPS), Via della Navicella 2, 00184 Roma, Italy \\ ${ }^{\mathrm{c}}$ Dipartimento di Biologia delle Piante Agrarie, Università di Pisa, Via del Borghetto 80, 56124 Pisa, Italy \\ d Centro per l'Agrobiologia e la Pedologia, Consiglio per la ricerca e la sperimentazione in Agricoltura (CRA-ABP), Via Lanciola 12/a, 50125 Firenze, Italy \\ e Land Lab, Scuola Superiore Sant'Anna, Piazza Martiri della Libertà 33, 56127 Pisa, Italy
}

\section{A R T I C L E I N F O}

\section{Article history:}

Received 23 January 2009

Received in revised form 30 October 2009

Accepted 7 November 2009

\section{Keywords:}

Soil quality

Organic farming

Stockless arable systems

Soil C cycle

Arbuscular mycorrhizal fungi

Soil microarthropods

\begin{abstract}
A B S T R A C T
Soil quality in Mediterranean conventional and organic stockless arable systems was assessed by a multidisciplinary approach. At the end of the first cycle of a 5-year crop rotation (2002-2006) in the Mediterranean Arable Systems Comparison Trial (MASCOT) long-term experiment, the effects of organic and conventional management systems were evaluated by using soil chemical, biochemical and biological parameters. Chemical and biochemical parameters linked to soil C cycle, arbuscular mycorrhizal fungi (AMF) and microarthropod communities were analysed according to a comparative approach. Results suggested a higher soil carbon sequestration in the organic respect to the conventional system, as shown by the values of total organic C (9.5 and $7.8 \mathrm{~g} \mathrm{~kg}^{-1}$, for organic and conventional system, respectively) and potentially mineralisable $\mathrm{C}\left(277\right.$ and $254 \mathrm{mg} \mathrm{kg}^{-1}$, for organic and conventional system, respectively). AMF population, AMF root colonisation and diversity of microarthropod population were slightly influenced by management system. On the other hand, mites/collembolans ratio was higher in conventionally than in organically managed soil (2.67 and 1.30 , respectively), indicating as organic managed soils were more disturbed than conventional ones, probably as the consequence of the more frequent soil tillage performed for mechanical weeds control.

The overall results demonstrated that, even in the short-term, the implementation of organically managed stockless systems in Mediterranean areas determined significant changes of some attributes for soil quality evaluation.
\end{abstract}

(c) 2009 Elsevier B.V. All rights reserved.

\section{Introduction}

Agroecosystem management can affect soil quality in the longterm by modifying soil physical, chemical and biological characteristics at a rate that is largely dependent on climate conditions and farming practice. According to one of the most widely accepted definitions, soil quality is "the capacity of a soil to function within ecosystem boundaries to sustain biological productivity, maintain environmental quality and promote plant and animal health" (Doran and Parkin, 1994). Soil quality cannot be measured directly but can be assessed through the measurements of changes of some of its attributes which are considered as indicators. On this basis, in the last decade, a number of studies aimed at detecting changes in soil quality and fertility by using selected soil parameters have been carried out (Schloter et al., 2005; Happerly et al., 2006;

\footnotetext{
* Corresponding author.

E-mail address: stefano.canali@entecra.it (S. Canali).
}

Melero et al., 2006; Mueller et al., 2006; Porter et al., 2006; Van Diepeningen et al., 2006).

Biodynamic and organic farming can improve soil quality in the long-term through their approach to the agroecosystem management based on crop rotation complexity, use of green manure and cover crops, crop residue recycling and application of organic fertilisers and amendments (Reganold et al., 1993; Drinkwater et al., 1998; Mäder et al., 2003; Sayre, 2005; Happerly et al., 2006; Schrader et al., 2006).

Soil quality in conventionally and organically managed systems may be evaluated utilising chemical, biochemical and biological parameters (Park and Seaton, 1996). In particular, since organic carbon (C) and C cycle determine soil functioning, biological, chemical and biochemical parameters linked to soil C cycle (i.e. humic C content, microbial C biomass, carbon mineralisation) have often been used for soil quality evaluation (Herrick and Wander, 1997; Fließach and Mäder, 2000; Schloter et al., 2005). Within the soil biota, arbuscular mycorrhizal fungi (AMF) are fundamental organisms for soil fertility and plant 
nutrition (Smith and Read, 1997). They live in symbiosis with the roots of most terrestrial plant species, representing a living bridge for the translocation of nutrients from soil to plant roots and of $\mathrm{C}$ from plant roots to the soil (Miller and Jastrow, 2000; Zhu and Miller, 2003). In agroecosystems, agricultural practices such as ploughing, chemical fertilisation and pesticide application affect the occurrence of AMF, decreasing soil biological activity (Johnson and Pfleger, 1992; Helgason et al., 1998). Lastly, since a wellbalanced soil arthropod community is essential in decomposing crop residues to form humus and recycling mineral nutrients for successive crops, the number and diversity of soil microarthropods can also be considered as part of the biological data set utilised for soil quality evaluation (De Goede and Brussaard, 2001).

However, soil quality indicator changes can only be assessed in the long run, applying the same agricultural practices year after year. For this reason, long-term experiments (LTE) are particularly important for the evaluation of soil quality in organic and/or biodynamic farming systems since the latter require several years from conversion to reach a new equilibrium (Köpke, 2006). The majority of LTE carried out to evaluate the effect of organic and/or biodynamic farming systems are based on mixed farming systems, reflecting the typical agricultural model of the region where they are performed (mainly temperate climates). Despite the basic principles of organic farming, which affirm the need for functional interconnections between crop and animal production, organic farming systems in the Mediterranean basin are often stockless (Canali and Speiser, 2005). In these systems, one of the main problems is soil organic matter conservation and mineral nutrient reintegration (Berry et al., 2003; Cormack et al., 2003).

This paper aims to evaluate the effects of organic and conventional management systems on soil quality focusing on a Mediterranean long-term experiment (Mediterranean Arable Systems Comparison Trial, MASCOT) (Bàrberi and Mazzoncini, 2006) that compares stockless organic and conventional arable cropping systems.

\section{Materials and methods}

\subsection{Description of the long-term field experiment}

The MASCOT long-term experiment started in autumn 2001 at the Interdepartmental Centre for Agro-environmental Research "Enrico Avanzi" (CIRAA) of the University of Pisa. CIRAA is located at S. Piero a Grado, Pisa (latitude $43^{\circ} 40^{\prime}$ N, longitude $10^{\circ} 19^{\prime} \mathrm{E}$ ), in the coastal plain of Tuscany, central Italy. At the end of the conversion period (October 2001), a 5-year stockless arable crop rotation was established in conventional and organic systems. Initially the rotation was: sugar beet (Beta vulgaris L. var. saccharifera)-common wheat (Triticum aestivum L.)-sunflower (Helianthus annuus L.)-pigeon bean (Vicia faba L. var. minor)-durum wheat (Triticum durum Desf.). In spring 2006, sugar beet was replaced by grain maize (Zea mays L.). In the organic system, red clover (Trifolium pratense L.) was undersown in common and durum wheat and subsequently used as a green manure for sunflower or sugar beet (maize). The total experimental area (24 ha) was divided into fields of $0.35-1$ ha each. The five crops in the rotation were allocated to five fields in each block and managed organically or conventionally (each group of five fields represents a system within a block; each crop is present every year) (Fig. 1). Systems were replicated three times according to a randomised complete block (RCB) design. Additional information on the agricultural practices used for the organic and conventional systems can be found in Bàrberi and Mazzoncini (2006).

\begin{tabular}{|c|c|c|c|c|c|c|c|c|c|c|}
\hline $\mathrm{F} 1$ & F2 & $\mathrm{F3}$ & $\mathrm{F} 4$ & $\mathrm{F5}$ & F6 & F7 & F8 & $\mathrm{F9}$ & $\mathrm{F} 10$ & F11 \\
\hline \multicolumn{5}{|c|}{ ORGANIC } & & \multicolumn{5}{|c|}{ CONVENTIONAL } \\
\hline $\begin{array}{c}\text { M } \\
\text { A } \\
\text { I } \\
\text { Z } \\
\text { E }\end{array}$ & $\begin{array}{l}C \\
O \\
M \\
M \\
O \\
N \\
\\
W \\
H \\
E \\
A \\
T \\
+ \\
G \\
M\end{array}$ & $\begin{array}{c}S \\
U \\
N \\
F \\
L \\
O \\
W \\
E \\
R\end{array}$ & $\begin{array}{l}\text { P } \\
\text { I } \\
\text { G } \\
\text { E } \\
\text { O } \\
\mathrm{N} \\
\\
\text { B } \\
\text { E } \\
\text { A } \\
N\end{array}$ & $\begin{array}{l}D \\
U \\
R \\
U \\
M \\
W \\
H \\
H \\
A \\
T \\
+ \\
G \\
M\end{array}$ & $\begin{array}{l}\text { I } \\
\text { C } R \\
\text { OA } \\
\text { S } \\
\text { G } \\
G \\
\text { C U } \\
\text { C } \\
\text { A U } \\
R \\
E\end{array}$ & $\begin{array}{c}M \\
A \\
\text { I } \\
Z \\
E\end{array}$ & $\begin{array}{l}C \\
O \\
M \\
M \\
O \\
N \\
\\
W \\
H \\
E \\
A \\
T\end{array}$ & $\begin{array}{c}S \\
U \\
N \\
F \\
L \\
O \\
W \\
E \\
R\end{array}$ & \begin{tabular}{|c}
$\mathrm{P}$ \\
$\mathrm{I}$ \\
$\mathrm{G}$ \\
$\mathrm{E}$ \\
$\mathrm{O}$ \\
$\mathrm{N}$ \\
$\mathrm{B}$ \\
$\mathrm{E}$ \\
$\mathrm{A}$ \\
$\mathrm{N}$
\end{tabular} & \begin{tabular}{|l} 
D \\
U \\
R \\
U \\
M \\
W \\
H \\
E \\
A \\
T
\end{tabular} \\
\hline
\end{tabular}

Fig. 1. Layout of one block of the MASCOT long-term experiment in 2006. Every crop was grown in each year. F, Field; GM, green manure.

\subsection{Climate}

Climatic conditions at the experimental site are typical of Mediterranean areas, with rainfall mostly concentrated in autumn (October to December) and spring (March to April). Due to elevated air temperatures, potential evapotranspiration is generally high in late spring and summer (up to 6-7 mm day ${ }^{-1}$ ). In the first crop rotation cycle of the experiment (2002-2006), rainfall and air temperature varied greatly. In particular, the first year (2002) was characterised by unusually high rainfall in late spring and summer, while 2003 was the driest of the latest 20 years with poor precipitation from late winter onwards.

\subsection{Crop yield and carbon input}

Fresh samples of crop grain yield, crop residues and weed biomass were assessed yearly in each field at harvest time $\left(1 \mathrm{~m}^{2}\right.$ sampling area per $1000 \mathrm{~m}^{2}$ ) and oven dried at $70{ }^{\circ} \mathrm{C}$ until constant weight. In the case of red clover green manure, total and weed biomass were sampled immediately before ploughing under.

In this study, crop yield data have been used to estimate $C$ input to the soil from each system, including roots and weeds (data from 2002 to 2004 are reported in Bàrberi and Mazzoncini, 2006; data from 2005 and 2006 are unpublished) to better understand the effects of crop management systems on soil chemical biological and microbiological properties. The $\mathrm{C}$ input was estimated using a concentration of $0.4 \mathrm{~kg} \mathrm{C} \mathrm{kg}^{-1}$ dry matter (DM) in shoots and roots (Johnson et al., 2006).

In both systems, crop residues were incorporated in soil at ploughing depth $(\mathrm{ca} .30 \mathrm{~cm})$ except in the conventional wheat crops, whose residues (straw) were removed from the field. In this case, wheat $C$ input was calculated by assuming stubble to represent $14 \%$ of the aboveground wheat biomass, as measured in MASCOT's fields after harvest. Root biomass at harvest in the first $30 \mathrm{~cm}$ soil depth was estimated as $10 \%$ of crop biomass (harvested grain + aboveground biomass) in the case of wheat and $15 \%$ in the case of sunflower and maize, according to previous studies carried out by the authors (Mazzoncini et al., unpublished). Carbon from rhizodeposits (root exudates, root hairs, etc.) were calculated according to Bolinder et al. (2007). 


\subsection{Soil sampling}

The MASCOT experiment is carried out on a loamy soil (Tipic Xeropsamment), whose main characteristics at the beginning of the experiment were the following: organic $C 9.35 \mathrm{~g} \mathrm{~kg}^{-1}$; total $\mathrm{N}$ $1.1 \mathrm{~g} \mathrm{~kg}^{-1} ; \mathrm{pH}$ 8.4. Sampling for soil quality evaluation was carried out in autumn 2006 (i.e. at the end of the first 5-year rotation cycle). Samples were collected in the six fields (three organically and three conventionally managed) in which durum wheat was grown in the 2001-2002 season (i.e. at the beginning of the experiment). Therefore, in these fields the crop sequence was: durum wheat (2002)-sunflower (2003)-pigeon bean (2004)common wheat (2005)-maize (2006).

Sampling and storing protocols were based on the parameters to be measured. In particular, soil was sampled in three different ways for determination of (i) chemical and biochemical parameters, (ii) AMF and (iii) microarthropod communities respectively.

\subsubsection{Soil sampling for chemical and biochemical analyses.}

For each of the sampled fields, four sub-samples were collected at $0-25 \mathrm{~cm}$ soil depth, air-dried, crushed and passed through a 2mm sieve (USDA-NRCS, 1996). Sub-samples were thoroughly mixed and stored for subsequent analyses. All the laboratory tests were carried out in three replicates in order to control intralaboratory variability.

\subsubsection{Soil and root sampling for AMF and mycorrhizal colonisation assessment}

For AMF assessment, three soil samples were collected from each field. Each soil sample (ca. $1000 \mathrm{~g}$ ) consisted of 7 random cores, which were pooled after sampling, collected at a $15-\mathrm{cm}$ soil depth using a $5-\mathrm{cm}$ diameter probe. Once pooled, samples were stored at $4{ }^{\circ} \mathrm{C}$ until analysis.

To assess mycorrhizal colonisation, the roots of wheat cultivated after maize were sampled from either organic and conventional plots by taking 8 sub-samples plot $^{-1}$. Root samples (2-3 cm length) were placed in polyethylene bags and stored at $4{ }^{\circ} \mathrm{C}$ until analysis. All the laboratory tests were carried out in triplicates.

\subsubsection{Soil sampling for microarthropod community analysis}

Four soil cores $(7 \mathrm{~cm} \times 5 \mathrm{~cm}, 5-7 \mathrm{~cm}$ deep) were taken in each of the six plots and then separately processed for extraction of microarthropods.

\subsection{Determination of soil chemical parameters}

\subsubsection{Total organic carbon, humification parameters and total nitrogen}

Total soil organic carbon ( $C_{\text {org }}$ ) was determined by mineralisation with $2 \mathrm{~N} \mathrm{~K}_{2} \mathrm{Cr}_{2} \mathrm{O}_{7}$ and $96 \% \mathrm{H}_{2} \mathrm{SO}_{4}$ solutions at $160{ }^{\circ} \mathrm{C}$ for $10 \mathrm{~min}$ according to Springer and Klee (1954). The content of organic carbon was calculated by back-titration with a solution of $0.2 \mathrm{~N}$ $\mathrm{FeSO}_{4}$.

For total extractable organic carbon $\left(C_{\text {extr }}\right)$ determination, each soil sample $(5 \mathrm{~g})$ was extracted by adding $100 \mathrm{~mL}$ of $0.1 \mathrm{~N} \mathrm{NaOH} /$ $0.1 \mathrm{~N} \mathrm{Na}_{4} \mathrm{P}_{2} \mathrm{O}_{7}$ solution at $65{ }^{\circ} \mathrm{C}$ for $48 \mathrm{~h}$, under $\mathrm{N}_{2}$ atmosphere. Aliquots of each $\mathrm{NaOH} / \mathrm{Na}_{4} \mathrm{P}_{2} \mathrm{O}_{7}$ extract were stored under $\mathrm{N}_{2}$ at $4{ }^{\circ} \mathrm{C}$. The same procedure utilised for $C_{\text {org }}$ determination was used on $10 \mathrm{~mL}$ of the $\mathrm{NaOH} / \mathrm{Na}_{4} \mathrm{P}_{2} \mathrm{O}_{7}$ extracts for determining extractable organic carbon $\left(C_{\text {extr }}\right)$.

Humic acids (HA) were precipitated from $25 \mathrm{~mL}$ of the extract by adding a solution of $50 \% \mathrm{H}_{2} \mathrm{SO}_{4}$, drop by drop until $\mathrm{pH}<2$. After centrifugation at $2500 \mathrm{rpm}$, the non-humified fraction was eliminated from the solution containing fulvic acids (FA) by purification on a polyvinylpyrrolidone column (PVP) (Ciavatta et al., 1990). Humic and fulvic acid carbon $\left(C_{\mathrm{HA}+\mathrm{FA}}\right)$ determination was performed as reported above, on $10 \mathrm{~mL}$ of $0.5 \mathrm{~N} \mathrm{NaOH}$ solutions (Ciavatta and Govi, 1993).

Humification parameters, such as the humification rate (HR) and the degree of humification (DH), were calculated as follows (Ciavatta et al., 1990):

$$
\begin{aligned}
& \mathrm{HR}(\%)=\left(\frac{C_{\mathrm{HA}+\mathrm{FA}}}{C_{\text {org }}}\right) \times 100 \\
& \mathrm{DH}(\%)=\left(\frac{C_{\mathrm{HA}+\mathrm{FA}}}{C_{\text {extr. }}}\right) \times 100
\end{aligned}
$$

Total soil nitrogen $\left(N_{\text {tot }}\right)$ was determined by Kjeldahl's procedure (Bremner and Mulvaney, 1982).

\subsubsection{Isoelectric focusing of humic substances}

Humic substances to be analysed by isoelectric focusing (IEF) were obtained as follows: a $0.5 \mathrm{~N} \mathrm{HCl}$ solution was added, drop-bydrop until $\mathrm{pH}<2$, to $20 \mathrm{~mL}$ of $0.1 \mathrm{~N} \mathrm{NaOH} / 0.1 \mathrm{~N} \mathrm{Na}_{4} \mathrm{P}_{2} \mathrm{O}_{7}$ soil extracts. After centrifugation at $2500 \mathrm{rpm}$, the supernatant was discharged and the precipitate was re-solubilised with $0.5 \mathrm{~N} \mathrm{NaOH}$ solutions, quantitatively transferred into a calibrated $25 \mathrm{~mL}$ flask, brought to volume with the same solution and stored under $\mathrm{N}_{2}$ at $4{ }^{\circ} \mathrm{C}$. Ten millilitres of this solution was dialysed in 6.000-8.000 Da membranes (Spectra/Por ${ }^{\circledR}$ ), then lyophilised and finally subjected to IEF.

The IEF separation was carried out in a Multiphore II, LKB electrophoretic cell, as described in Govi et al. (1994). This electrophoretic technique is able to fractionate mixtures of organic compounds, such as humic acids, on the basis of their isoelectric point and their electrophoretic mobility (De Nobili et al., 1989; Govi et al., 1994; Dell'Abate et al., 2002; Alianiello and Baroccio, 2004). An IEF profile was obtained for each soil sample. This qualitative information was converted into a quantitative one by calculating the $A_{s} \%$ for each profile according to the following approach: IEF peaks were numbered, and the peaks area were determined for each soil IEF profile, assuming the area under the entire IEF profiles as $100 \%$. The relative sum of peaks areas focused at $\mathrm{pH}>4.5$ (corresponding to more humified organic matter) was calculated and named $A_{\mathrm{s}} \%$.

\subsection{Determination of soil biochemical parameters}

\subsubsection{Soil C mineralisation}

Soil $\mathrm{C}$ mineralisation was studied by measuring $\mathrm{CO}_{2}-\mathrm{C}$ production in closed jars (Isermeyer, 1952). Each soil sample ( $25 \mathrm{~g}$, oven dry-weight equivalent) was rewetted to their $-33 \mathrm{kPa}$ water tension and incubated at $30{ }^{\circ} \mathrm{C}$. The $\mathrm{CO}_{2}$ evolution was determined by back titration of $\mathrm{NaOH}$ absorbed $\mathrm{CO}_{2}$ at the 1 st $\left(C_{1}\right), 2$ nd, 4th, 7th, 10th, 14th, 17th and 21st day of the incubation period. The $\mathrm{CO}_{2}-\mathrm{C}$ measured after the first day of incubation $\left(C_{1}\right)$ represents the soil easily mineralisable $C$. The average value of $\mathrm{CO}_{2}-\mathrm{C}$ evolution at the 21 st day of incubation was assumed as soil basal respiration $\left(C_{\text {basal }}\right)$, indicating the steady rate of respiration in soil which originates from the turnover of organic matter. According to Pell et al. (2005), basal respiration may constitute an integrated index of the potential of the soil biota to degrade organic substances under given environmental conditions. The kinetic study of the organic $C$ dynamics was performed by fitting the cumulative $\mathrm{CO}_{2}-\mathrm{C} v s$ time according to a first-order exponential function $\left[C_{\mathrm{t}}=C_{0}\left(1-e^{-k t}\right)\right]$. This allowed us to calculate the potentially mineralisable $C$ pool $C_{0}$ for each soil.

\subsubsection{Microbial biomass $C$}

Carbon of soil microbial biomass $\left(C_{\mathrm{mic}}\right)$ was measured by the chloroform fumigation-extraction method (Vance et al., 1987) on 
air-dried soil samples conditioned by a 21-day incubation in open glass jars at $-33 \mathrm{kPa}$ water tension and $30^{\circ} \mathrm{C}$. Soil samples were incubated for restoring the microbial activity of air-dried soils.

\subsubsection{Metabolic quotient, mineralisation coefficient and $C_{\text {mic }} / C_{\text {org }}$ ratio}

The metabolic quotient $q\left(\mathrm{CO}_{2}\right)$, defined as specific soil respiration of the microbial biomass, was calculated as ratio of basal respiration values (after the 21st day) and microbial biomass C according to Anderson and Domsch (1985). The mineralisation coefficient $C_{\min }$, defined as the ratio of mineralised soil $\mathrm{C}$ at equilibrium conditions and the total amount of soil organic $C$, was calculated according to Dommergues (1960). The ratio $C_{\text {mic }} / C_{\text {org }}$ was used as an index of microbial biomass contribution to soil organic C (Anderson and Domsch, 1989).

\subsection{Determination of soil biological parameters}

\subsubsection{AMF spore assessment}

AMF spores and sporocarps were extracted from soil subsamples ( $50 \mathrm{~g}$ ) by wet-sieving and decanting, down to a mesh size of $50 \mu \mathrm{m}$ (Gerdemann and Nicolson, 1963), flushed into Petri dishes, and examined under a dissecting microscope (Wild, Leica, Milano, Italy).

Numbers and morphotypes of AMF spores were recorded. When present, sporocarps were dissected with forceps and released spores were counted. Spores were isolated by using capillary pipettes, mounted on microscope slides in polyvinyl alcohol lacto-glycerol (PVLG), examined under a Polyvar light microscope (Reichert-Young, Vienna, Austria) and identified following current species descriptions and identification manuals (Gerdemann and Trappe, 1974; Schenck and Perez, 1990). At least 50 spores of each morphotype were observed and measured by using Quantimet 500 image analysis software (Leica, Milan, Italy).

\subsubsection{Assessment of mycorrhizal colonisation}

The sampled roots were washed under tap water, cleared in 10\% $\mathrm{KOH}$, acidified and stained with Trypan blue in lactic acid, then washed and stored in lactic acid until analysis (Phillips and Hayman, 1970). Assessment of percent root length colonised by AMF was carried out under a wild dissecting microscope (Leica, Milan, I) following the gridline intersect method (Giovannetti and Mosse, 1980).

\subsubsection{Microarthropod community evaluation}

The microarthropods were extracted using Berlese-Tullgren funnels for a minimum of 4 days and preserved in $95 \%$ ethanol $+1 \%$ glycerol mixture. Animals were counted and identified until order or suborder level. The synthetic index of degree of diversity change of an ecological system $(\Delta V)$ proposed by Cancela da Fonseca and Sarkar (1996) was used to compare the differences in biodiversity on the basis of the following four groups: oribatid mites (Cryptostigmata), other mites (Astigmata, Prostigmata, Mesostigmata), Collembola and other arthropods. In $\Delta V_{\text {global, each of five }}$ parameters taken in account for index calculation were obtained as the sum of means of data, whereas in $\Delta V_{\text {mean }}$, as the mean of sums (for more details see Cancela da Fonseca and Sarkar, 1996). These indices range between -1 and +1 . The absolute value measures the difference between the two systems, the sign being positive if in system taken as control (conventional) the degree of diversity is lower.

Arthropod biodiversity and biological soil quality were evaluated using the BSQ index proposed by Parisi (2001), based on quick and practical evaluation of soil microarthropods, avoiding classification at species level, but considering the morphological features from the point of view of their adaptation to edaphic environment. For this purpose, the soil microarthropods were arranged on the basis of Ecomorphological Index (EMI) tables (Parisi, 2001; Gardi et al., 2002; Parisi et al., 2005). The EMI tables assign scores to each group; the scores are graduated with highest values for microarthropod with highest edaphic adaptation. BSQ index represents the sum of all scores assigned to groups found in the considered system.

\subsection{Statistical analysis}

Data of $C$ input, soil chemical and biochemical parameters, AMF and root mycorrhizal colonisation were subjected to univariate analysis of variance (ANOVA). Microarthropod abundance data were analysed by multivariate analysis of variance (MANOVA). All ANOVAs and MANOVAs were performed using treatment (conventional $v s$ organic), block and replicate as independent variables, and $t$-tests $(P \leq 0.05)$ to compare treatment means. The comparison among frequencies of microarthropods was carried out by Chisquare test $(P \leq 0.05)$. All statistical analyses were carried with SPSS 13.0 (SPSS Inc., 1994).

\section{Results}

\subsection{Carbon input}

Compared to the conventional system, significant increases in C input in the organic system were observed in 4 years out of 5 (2002, 2003, 2005 and 2006) (Table 1). In 2002 and 2005, the higher quantities of carbon overall sequestered by the organic system can be ascribed to the higher quantity of $C$ from crop residues, since in the organic system wheat straw was retained in the field while in the conventional system it was removed. In 2003 and 2006, the introduction of a winter green manure crop in the organic system resulted in higher carbon input. In 2004, when pigeon bean was cultivated, the quantity of carbon retained did not differ between the organic and conventional systems because the productivity of this crop was not influenced by the management system and because its plant residues were retained in both systems. At the end of the first crop rotation cycle, the organic system received a higher $C$ input $(43 \%)$ than the conventional one $\left(16.9 \mathrm{tha}^{-1}\right.$ vs $11.8 \mathrm{t} \mathrm{ha}^{-1}$ respectively) (Table 1 ).

\subsection{Chemical parameters}

The mean values of the chemical and biochemical parameters chosen to evaluate soil quality are shown in Table 2.

The $C_{\text {org }}$ mean value was significantly higher in organic than in conventional plots $\left(9.5 \mathrm{gC} \mathrm{kg}_{\text {soil }}^{-1} \mathrm{vs} .7 .8 \mathrm{gC} \mathrm{kg}_{\text {soil }}^{-1}\right.$, respectively). Results on the different soil organic $\mathrm{C}$ fractions indicated that both the extractable $C$ in alkaline environment $\left(C_{\text {extr }}\right)$ and the humified $\mathrm{C}\left(\mathrm{C}_{\mathrm{HA}+\mathrm{FA}}\right)$ did not significantly differ between the organic and conventional systems. Similarly, the humification degree (DH\%) was not significantly influenced by management system, while the soil humification rate (HR\%) was higher (26\%) in the conventional system. No significant differences between organic and conventional systems were observed for the $A_{s} \%$ parameter as well as for total $\mathrm{N}$.

\subsection{Biochemical parameters}

Mean values of mineralised $C$ after the 1 st day $\left(C_{1}\right)$, of potentially mineralised $C\left(C_{0}\right)$ and of basal respiration $C\left(C_{\text {basal }}\right)$ were higher in organic than in conventional soils of $17 \%, 18 \%$ and $9 \%$, respectively (Table 2 ). In contrast, the ratio between $C_{\text {basal }}$ and $C_{\text {org }}\left(C_{\text {min }}\right)$ did not differ between management systems. 
Table 1

Estimated carbon input $\left(\mathrm{tha}^{-1}\right)$ to the organic and conventional systems.

\begin{tabular}{|c|c|c|c|c|c|c|c|c|c|}
\hline \multirow[t]{3}{*}{ C source } & \multirow[t]{3}{*}{ System } & \multicolumn{8}{|c|}{ Crop and harvest year } \\
\hline & & Durum wheat & Red clover & Sunflower & Pigeon bean & Common wheat & Red clover & Maize & Total C \\
\hline & & 2002 & 2003 & 2003 & 2004 & 2005 & 2006 & 2006 & $2002-2006$ \\
\hline \multirow[t]{2}{*}{ Crop residues } & Organic & $2.15 \mathrm{a}$ & 0.98 & 1.37 & 1.49 & $1.86 \mathrm{a}$ & 0.98 & $2.27 \mathrm{a}$ & $11.10 \mathrm{a}$ \\
\hline & Conventional & $0.80 \mathrm{~b}$ & - & 1.60 & 1.43 & $0.64 \mathrm{~b}$ & - & $2.79 \mathrm{~b}$ & $7.26 \mathrm{~b}$ \\
\hline \multirow[t]{2}{*}{ Crop roots } & Organic & 0.38 & 0.13 & 0.32 & 0.32 & 0.36 & 0.13 & 0.66 & 2.30 \\
\hline & Conventional & 0.57 & - & 0.38 & 0.30 & 0.46 & - & 0.81 & 2.52 \\
\hline \multirow[t]{2}{*}{ Rhizodeposit } & Organic & 0.25 & 0.08 & 0.21 & 0.20 & 0.24 & 0.08 & 0.43 & 1.49 \\
\hline & Conventional & 0.37 & & 0.25 & 0.20 & 0.30 & & 0.53 & 1.65 \\
\hline \multirow[t]{2}{*}{ Weeds } & Organic & 0.01 & 0.02 & 0.00 & 0.05 & 0.06 & 0.76 & 0.00 & $0.90 \mathrm{a}$ \\
\hline & Conventional & 0.00 & - & 0.00 & 0.25 & 0.16 & - & 0.00 & $0.41 \mathrm{~b}$ \\
\hline \multirow[t]{2}{*}{ Fertilisers } & Organic & 0.28 & - & 0.28 & - & 0.28 & - & 0.28 & 1.12 \\
\hline & Conventional & - & - & - & - & - & - & - & - \\
\hline \multirow[t]{2}{*}{ Total C input } & Organic & $3.07 \mathrm{a}$ & 1.21 & 2.18 & 2.06 & $2.80 \mathrm{a}$ & 1.95 & 3.64 & $16.91 \mathrm{a}$ \\
\hline & Conventional & $1.74 \mathrm{~b}$ & - & 2.23 & 2.18 & $1.56 \mathrm{~b}$ & - & 4.13 & $11.84 \mathrm{~b}$ \\
\hline
\end{tabular}

Note: Within column and year, means followed by letters are significantly different at $P \leq 0.05$ ( $t$ test).

Soil microbial biomass $\left(C_{\text {mic }}\right)$ was not different in the organic and in the conventional system. Similarly, the mineralised $C$ per unit of microbial biomass $\mathrm{C}\left(q \mathrm{CO}_{2}\right)$ did not significantly differ between crop management systems. On the other hand, $C_{\text {mic }} / C_{\text {org }}$ ratio was higher in the conventional than in the organic system $\left(4.11\left(\mathrm{mg} \mathrm{kg}^{-1}\right) \times 10^{3}\right.$ vs $\left.3.48\left(\mathrm{mg} \mathrm{kg}^{-1}\right) \times 10^{3}\right)$.

\subsection{Biological parameters}

\subsubsection{AMF spore population}

Total number of spores did not significantly differ between management systems (361.6 and 445.4 spores $50 \mathrm{~g}^{-1}$ soil in organic and conventional, respectively).

The AMF species in the experimental site belonged to the genera Glomus and Scutellospora and were: Glomus badium Oehl, Redecker \& Sieverd., Glomus etunicatum (Becker \& Gerdemann), Glomus geosporum (Nicol. \& Gerd.) Walker, Glomus mosseae (Nicol. \& Gerd.) Gerdemann and Trappe, Glomus rubiforme (Gerd. \& Trappe) R.T. Almeida \& N.C. Schenck (Basionym: Sclerocystis rubiformis Gerdemann and Trappe), Glomus sinuosum (Gerdemann

Table 2

Mean chemical and biochemical parameters measured in the organic and conventional systems.

\begin{tabular}{lcc}
\hline Parameter & Organic & Conventional \\
\hline$C_{\text {org }}\left(\mathrm{g} \mathrm{kg}^{-1}\right)$ & $9.5 \mathrm{a}$ & $7.8 \mathrm{~b}$ \\
$C_{\text {extr }}\left(\mathrm{g} \mathrm{kg}^{-1}\right)$ & 6.9 & 6.6 \\
$C_{\mathrm{HA}+\mathrm{FA}}\left(\mathrm{g} \mathrm{kg}^{-1}\right)$ & 5.2 & 5.3 \\
$\mathrm{HR}(\%)$ & $54.6 \mathrm{~b}$ & $68.9 \mathrm{a}$ \\
$\mathrm{DH}(\%)$ & 75.1 & 79.1 \\
$A_{\mathrm{s}}(\%)$ & 63.0 & 60.6 \\
Total N $\left(\mathrm{g} \mathrm{kg}^{-1}\right)$ & 1.1 & 1.0 \\
$\mathrm{C} / \mathrm{N}$ & $8.6 \mathrm{a}$ & $7.5 \mathrm{~b}$ \\
$C_{1}\left(\mathrm{mg} \mathrm{C}-\mathrm{CO}_{2} \mathrm{~kg}^{-1} \mathrm{~d}^{-1}\right)$ & $55.2 \mathrm{a}$ & $47.1 \mathrm{~b}$ \\
$C_{\mathrm{basal}}\left(\mathrm{mgCO}_{2}-\mathrm{C} \mathrm{kg}^{-1}\right)$ & $7.9 \mathrm{a}$ & $6.7 \mathrm{~b}$ \\
$C_{0}\left(\mathrm{mg} \mathrm{CO}_{2}-\mathrm{C} \mathrm{kg}^{-1}\right)$ & $277 \mathrm{a}$ & $254 \mathrm{~b}$ \\
$C_{\text {mic }}\left(\mathrm{mg} \mathrm{kg}^{-1}\right)$ & 33.4 & 30.3 \\
$q\left(\mathrm{CO}_{2}\right)\left(\mathrm{mg} \mathrm{CO}_{2}-\mathrm{C} \mathrm{mg} \mathrm{C}_{\text {mic }}^{-1} \mathrm{~d}^{-1}\right)$ & 0.24 & 0.23 \\
$C_{\text {min }}\left(\mathrm{mg} \mathrm{CO}_{2}-\mathrm{C} \times \mathrm{kg}^{-1}\right.$ soil $\left.\times \mathrm{d}^{-1}\right) /$ & 0.83 & 0.86 \\
$\left(\mathrm{mg} \mathrm{C}_{\text {org kg }}{ }_{\text {soil }}\right) \times 10^{3}$ & & \\
$C_{\text {mic }} / C_{\text {org }}\left(\mathrm{mg} \mathrm{kg}^{-1}\right) \times 10^{3}$ & $3.48 \mathrm{~b}$ & $4.11 \mathrm{a}$ \\
\hline
\end{tabular}

$C_{\text {org }}$ : Total organic $\mathrm{C} ; C_{\text {ext }}$ : total extractable organic carbon; $C_{\mathrm{HA}+\mathrm{FA}}$ : humic and fulvic C; HR: humification rate; $\mathrm{DH}$ : degree of humification; $A_{\mathrm{s}}$ : peaks areas focused at $\mathrm{pH}>4.5 ; C_{1}: \mathrm{CO}_{2}-\mathrm{C}$ evolution determined at the 1 st day of incubation; $C_{\text {basal }}$ : soil basal respiration; $C_{0}$ : potentially mineralisable $C ; C_{\text {mic }}$ : $C$ of soil microbial biomass; $q\left(\mathrm{CO}_{2}\right)$ : metabolic quotient; $C_{\min }$ : mineralisation coefficient $(P<0.05)$. See text for further explanation. Means followed by letters are significantly different at $P \leq 0.05$ ( $t$-test). and Bakshi) Almeida and Schenck (Basionym: Sclerocystis sinuosa Gerdemann and Bakshi), Scutellospora calospora (Nicol. \& Gerd.) Walker \& Sanders. In addition, two unidentified Glomus sp. morphotypes were recovered.

\subsubsection{Mycorrhizal colonisation of wheat plants}

Percentage of colonised root length of wheat plants were not significantly different, being 36.6 and 33.1 for organic and conventional system, respectively. An extensive arbuscular colonisation occurred in the roots of all wheat plants, irrespective of the origin of the sample (organic or conventional management). A few vesicles were detected in the root samples.

\subsubsection{Soil microarthropods}

A total of 808 and 1017 microarthropod individuals were collected in the organic and conventional systems, corresponding to about 19,200 and 24,200 individuals $\mathrm{m}^{-2}$, respectively. Treatments (i.e. the different management systems) slightly affected the abundance of microarthropod ranked as oribatid mites, other mites, collembolans and other arthropods (Wilks' Lambda $=0.03$ ). The differences were mainly due to the "other mites" group $(P=0.043)$ and in small part to the collembolan group $(P=0.054$, close to significance).

Despite the fact that abundance in the four microarthropod groups was not sensibly influenced by the management system, significant differences were observed in percent distribution of Astigmata and Prostigmata (belonging to "other mites" group) and partly in the Collembola group. As is usually observed in all soil types, oribatid mites and collembolans were the most representative groups: the first one prevailed in the conventional system whereas the second one prevailed in the organic system (Table 3 ). The global index of the degree of biodiversity change ( $\left.\Delta V_{\text {global }}\right)$ showed slightly greater biodiversity in the conventional systems $(-0.0200$, organic $v s$ conventional). However if $\Delta V_{\text {mean }}$ was taken into account, the differences were considerably lowered $(0.0014$, organic vs conventional).

The biological soil quality index (BSQ) was higher in the conventional fields than in the organic ones (112 and 99, respectively), due to the unique presence of Protura and Chilopoda in the conventional system (Table 4). Similarly, the mites/ collembolans ratio, usually considered a measure of environmental stability (Bachelier, 1986), was significantly $\left(\chi^{2}=50.43 ; P<0.001\right)$ higher in the conventional than in the organic system (2.67 and 1.30 , respectively). 
Table 3

Abundance (mean number of specimens per sample of $175 \mathrm{~cm}^{3} \pm \mathrm{SE}$ ) of soil microarthropods and their percent distribution among the different taxonomic groups.

\begin{tabular}{lllllc}
\hline & \multicolumn{2}{l}{ Organic } & & \multicolumn{2}{l}{ Conventional } \\
\cline { 2 - 3 } \cline { 5 - 6 } & Mean & $\%$ & & Mean & $\%$ \\
\hline Oribatida & 23.9 & $35.5 \mathrm{~b}$ & & 34.5 & $40.7 \mathrm{a}$ \\
Other mites & $12.2 \mathrm{~b}$ & & & $23.8 \mathrm{a}$ & \\
$\quad$ Astigmata & & $1.37 \mathrm{a}$ & & $0.10 \mathrm{~b}$ \\
Prostigmata & & $10.6 \mathrm{~b}$ & & $21.9 \mathrm{a}$ \\
Mesostigmata & & 6.57 & & 6.10 \\
Collembola & 27.9 & $41.5 \mathrm{a}$ & & 21.8 & $25.7 \mathrm{~b}$ \\
Other arthropods & 3.25 & 4.48 & & 4.58 & 5.41 \\
\hline
\end{tabular}

Note: Within a row, means followed by letters are significantly different at $P \leq 0.05$ ( $t$ test for absolute values and Chi square test for percent values).

Table 4

Ecomorphological index (EMI) of soil microarthropods used to calculate BSQ.

\begin{tabular}{lcc}
\hline Groups & Organic & Conventional \\
\hline Protura & - & 20 \\
Collembola & 20 & 20 \\
Psocoptera & 1 & - \\
Hemiptera (Aphididae) & 1 & - \\
Thysanoptera & 1 & 1 \\
Coleoptera & 6 & 6 \\
Diptera & 10 & 10 \\
Hymenoptera & 5 & 5 \\
Acari & 20 & 20 \\
Isopoda & 10 & - \\
Symphyla & 20 & 20 \\
Chilopoda & - & 10 \\
Araneida & 5 & - \\
\hline
\end{tabular}

\section{Discussion}

\subsection{Chemical and biochemical parameters}

The higher $C$ input observed under the organic system was more affected by management than by crop productivity. In a previous analysis of crop productivity within the same experiment (MASCOT), Bàrberi and Mazzoncini (2006) pointed out that the whole aboveground biomass produced by crops was lower under the organic system except for pigeon bean, the only legume crop in the rotation. Due to the crop residue conservation strategy and the inclusion of green manure crops in the rotation, the overall net primary production was greater in the organic than in the conventional system. As a consequence, the carbon fixed in crop residues and green manure, together with the organic carbon contained in the applied organic fertilisers, increased the carbon input to the organic soil. Of the total $\mathrm{C}$ input to the organic system in the first rotation cycle, $21 \%$ was attributable to crop residues (including roots and rhizodepositions), $47 \%$ to green manure, $22 \%$ to organic fertilisers and $10 \%$ to weed biomass. This result highlights the strategic importance of including green manure for managing organic carbon budget in organic agricultural systems under Mediterranean climatic conditions.

According to the hypothesis that $\mathrm{C}$ input is the key driver of soil organic matter changes (assuming as constant the other factors that affect $C$ mineralisation; Lugato et al., 2006) and considering that there is a strong positive relationship between $C$ input and soil organic C content (Larson et al., 1972; Havlin et al., 1990; Rasmussen and Collins, 1991; Paustian et al., 1992; Buyanovsky and Wagner, 1998; Canali et al., 2004; Lugato et al., 2006), our findings suggest a stronger capacity for carbon sequestration in the organic system compared to the conventional one. This is consistent with observations by other authors (Drinkwater et al., 1998; Mäder et al., 2003; Pimentel et al., 2005).
Soil organic matter quality in the two systems was similar, as demonstrated by the results obtained for extractable $C\left(C_{\text {extr }}\right)$, humification degree (DH\%) and IEF profiling $\left(A_{s} \%\right)$. Nevertheless, the higher value of humification rate $(\mathrm{HR} \%)$ in the conventional system can be explained by the significantly higher content of $C_{\text {org }}$ in the organic system, mainly due to soil application of labile organic matter deriving from crop residues and/or green manure. This also can explain the higher values of $\mathrm{C} / \mathrm{N}$ in the organic system.

Microbial activity, evaluated on the basis of soil respiration, showed results in accordance with soil organic $C$. Either $C_{1}, C_{0}$, and $C_{\text {basal }}$ values confirmed that in those conditions soil microorganisms had a greater amount of available substrates.

The similarity of the size of microbial populations $\left(C_{\text {mic }}\right)$, metabolic efficiency $\left(q \mathrm{CO}_{2}\right)$, and the $C_{\text {min }}\left(C_{\text {basal }} / C_{\text {org }}\right)$ ratios between the management systems might indicate that in Mediterranean conditions, despite the increase in $C$ input and the consequent greater amount of available $C$ substrates in the organic system, soil microorganisms followed the same metabolic pattern in both systems. These findings are in contrast with results obtained by Mäder et al. (2002) and Franca et al. (2007) who, however, carried out their studies in areas not characterised by a Mediterranean type of climate.

\subsection{Biological parameters}

The obtained results suggested that significant changes in AMF spore populations due to crop management system are unlikely to occur in a relatively short period ( 5 years).

Nine different AMF morphospecies belonging to the genera Glomus and Scutellospora were recovered in the experimental fields, showing that several spore types occur in Mediterranean environments (Calvente et al., 2004). Eight AMF morphotypes belonged to the genus Glomus, four of which were sporocarpic species (G. badium, G. mosseae, G. rubiforme and G. sinuosum), confirming data on the predominance of this genus in agricultural soils (Helgason et al., 1998; Oehl et al., 2003; Bedini et al., 2007).

AMF species belonging to the genus Scutellospora have been reported to be highly sensitive to anthropogenic disturbance and to agricultural practices such as tillage, chemical fertilisation and pesticide treatments (Giovannetti and Gianinazzi-Pearson, 1994; Helgason et al., 1998; Daniell et al., 2001; Jansa et al., 2002), while they have been often retrieved from undisturbed sandy soils (Blaszkowski et al., 2004; Rodriguez-Echeverrìa and Freitas, 2006). The occurrence of $S$. calospora in our experimental site may depend on soil alluvional origin, making it similar to a coastal sand dune system, where other Scutellospora species were recovered (Giovannetti, 1985; Blaszkowski et al., 2004; Turrini et al., 2008).

Similarly to what was observed for AMF spores, lack of significant differences in wheat root mycorrhizal colonisation suggests the absence of notable effects of different crop management systems on AMF population and colonisation ability in the short-term.

As for soil microarthropods, statistical analysis did not show substantial differences between the organic and conventional systems. The overall arthropod diversity is usually assumed to be higher in uncultivated (natural) systems than in cultivated ones (Solbrig, 1992; Cancela da Fonseca and Sarkar, 1996), in minimum tillage than in plough-based systems (Cortet et al., 2002) and generally in low-input systems (Siepel, 1996). The average density of mites retrieved in this study (10,334 and 16,659 individuals $\mathrm{m}^{-2}$ in the organic and conventional systems, respectively) was higher than that retrieved in intensive maize monoculture in different locations of the Po Valley (Northern Italy), where mite mean density ranged from 757 to 8509 individuals $\mathrm{m}^{-2}$ (Mahunka and Paoletti, 1984). The Collembola density varied from 20,000 to 40,000 individuals $\mathrm{m}^{-2}$ both in pesticide treated and untreated maize grown in Northern Italy (Sabatini et al., 1997) while, in our 
study, it was considerably lower (about 8000 and 6000 individuals $\mathrm{m}^{-2}$ in organic and conventional managed soils, respectively). This suggests that local site factors (e.g. soil and weather conditions) may also be important determinants of mite and collembolan abundance in agroecosystems. Mites normally are prevalent respect to the collembolans in stable environments and in quality soil (Bachelier, 1986). They are also more sensitive to drought (Lindberg and Bengtsson, 2005) and to some agricultural practices, as tillage (Ferraro and Ghersa, 2007; Tabaglio et al., 2009). This is in agreement with our results because mite/collembolan ratio is higher in conventional than in organic systems, in which disturbance for microarthopods was greater, probably, as consequence of the more frequent soil tillage performed for mechanical weeds control. The disturbance effects of tillage on soil microarthropod population is also confirmed by the global synthetic index of degree of change of diversity of an ecological system ( $\left.\Delta V_{\text {global }}\right)$. In fact, this value indicated a slightly higher biodiversity in conventional than in organic system.

Values of the BSQ have been shown to increase from about 50 , for highly disturbed soils, to about 120 in forestry soils and grassland (Parisi, 2001). In our experiment, BSQ of either conventionally and organically managed maize was higher than the BSQ recorded in permanent grassland and vineyards of the Po Valley (Gardi et al., 2002). Parisi et al. (2005) found analogous BSQ values in organic maize but near half of our value in conventional maize. Unexpectedly, in our study the BSQ index of the conventional system was higher than that of the organic system. However, the BSQ value of the latter was close to 100, indicating good soil quality (Parisi, 2001). Protura and Chilopoda, which in our experiment determined the higher BSQ in the conventional system, were present only with 1-2 individuals $\mathrm{m}^{-2}$. In Italy, Protura was not recorded in other soils cropped with maize and Chilopoda was more common in non-pesticide-treated maize (Parisi et al., 2005). The values $>1$ of the mites/collembola ratio confirmed good soil quality in both systems (Bachelier, 1986).

\section{Conclusions}

Higher $C_{\text {org }}$ in organically managed soil seemed to determine an analogous increase in the rate of mineralisation without determining changes in microbial population size, in its metabolic efficiency and in the accumulation of more labile soil organic matter. Despite the lack of animal residues (i.e. farmyard manure), plant biomass input due to ploughing under of crop residues, interseeding and green manure, induced a significant increase in $C_{\text {org }}$ in the organic system compared to the conventional system. During the first 5 years (2002-2006) of the experiment, plant material was partially mineralised inducing greater microbial activity in the organically managed soil, but the elapsed time may have been insufficient to increase the level of humified substances. The ongoing evolution of the experimental soils towards a new equilibrium may explain the substantial lack of crop management system effect in AMF spore population and wheat mycorrhizal root colonisation, while the more frequent tillage in organic maize may have negatively affected the presence of soil microarthropods, which (at least for oribatids, one of the most important components), require a longer time to respond to changes in soil organic matter (Behan-Pelletier, 1999; Lindberg and Bengtsson, 2005; Osler and Murphy, 2005).

In synthesis, all the studied parameters described a system in evolution where the organic $C$ stock has rapidly increased but soil metabolism is mainly oriented towards short-term utilisation of material and energy. These findings should be considered shortterm changes observed over 5 years since the introduction of organic management and are expected to continue to change over a longer period of time. Further assessments of the same biological, chemical and biochemical parameters in the same experimental fields are then needed in the years to come to verify long-term changes induced by organic management in an arable system.

\section{Acknowledgments}

The authors wish to thank the technical staff of CIRAA for their invaluable contribution to the set up and management of MASCOT and all the students who participated in sample collection and handling.

Many thanks also to Corrado Ciaccia of CRA-RPS for his help in soil chemical and biochemical analysis, to Sauro Simoni of CRAABP for his help in statistical analysis of mesofauna results, to Luciano Avio, Cristana Sbrana, and Stefano Bedini of the Dipartimento di Biologia delle Piante Agrarie-Università di Pisa for their valuable contribution in AMF spore and mycorrhizal colonisation assessment.

This study was carried out in the framework of the SIMBIOVEG (www.simbioveg.org) research project, funded by the Italian Ministry of University and Scientific Research.

\section{References}

Alianiello, F., Baroccio, F., 2004. Molecular weight fractions of soils and peat humic substances analyzed by isoelectric focusing. Commun. Soil Sci. Plant Anal. 35 2825-2835.

Anderson, T.H., Domsch, K.H., 1985. Determination of eco-physiological maintenance requirements of soil microorganism in a dormant state. Biol. Fertil. Soils $1,81-89$.

Anderson, T.H., Domsch, K.H., 1989. Ratios of microbial biomass carbon to total organic-C in arable soils. Soil Biol. Biochem. 21, 471-479.

Bachelier, G., 1986. La vie animale dans le soil. O.R.S.T.O.M., Paris, pp. 171-196.

Bàrberi, P., Mazzoncini, M., 2006. The MASCOT (Mediterranean Arable Systems Comparison Trial) long term experiment. In: Raupp, J., Pekrun, C., Oltmanns, M., Köpke, U. (Eds.), Long-term Field Experiments in Organic Farming. ISOFAR Scientific Series, Verlag, Berlin, pp. 1-14.

Bedini, S., Avio, L., Argese, E., Giovannetti, M., 2007. Effects of long-term cropping systems on arbuscular mycorrhizal fungal spore population and glomalinrelated soil protein. Agric. Ecosyst. Environ. 120, 463-466.

Behan-Pelletier, V., 1999. Oribatid mite biodiversity in agroecosystems: role for bioindication. Agric. Ecosyst. Environ. 74, 411-423.

Berry, P.M., Stockdale, E.A., Sylvester-Bradley, R., Philipps, L., Smith, K.A., Lord, E.I., Watson, C.A., Fortune, S., 2003. N, P and K budgets for crop rotations on nine organic farms in the UK. Soil Use Manage. 19 (2), 112-118.

Blaszkowski, J., Blanke, V., Renker, C., Buscot, F., 2004. Glomus aurantium and G. xanthium new species in Glomeromycota. Mycotaxon 90, 447-467.

Bolinder, M.A., Janzen, H.H., Gregorich, E.G., Angers, D.A., van den Bygaart, A.J., 2007 An approach for estimating net primary productivity and annual carbon inputs to soil for common agricultural crops in Canada. Agric. Ecosyst. Environ. 118 $29-42$.

Bremner, J.M., Mulvaney, C.S., 1982. Nitrogen total. In: Page, A.L. (Ed.), Methods of Soil Analysis, Part 2, second ed. Agron. Monogr. 9. ASA and SSSA, Madison, WI, pp. 595-624.

Buyanovsky, G.A., Wagner, G.H., 1998. Changing role of cultivated land in the global carbon cycle. Biol. Fertil. Soil 27, 242-245.

Calvente, R., Cano, C., Ferrol, N., Azcon-Aguilar, C., Barea, J.M., 2004. Analysing natural diversity of arbuscular mycorrhizal fungi in olive tree (Olea europaea $\mathrm{L}$.) plantations and assessment of the effectiveness of native fungal isolates as inoculants for commercial cultivars of olive plantlets. Appl. Soil Ecol. 26, 11-19.

Canali, S., Speiser, B., 2005. Current evaluation procedures for fertilizers and soil conditioners used in organic farming. In: Proceedings of a Workshop of the Organic Input Evaluation Project (ORGIN), Emerson College (UK), Research Institute for Organic Farming (FiBL), Frick CH, 29-30 April 2004, p. 100 (ISBN 3-906081-65-6).

Canali, S., Trinchera, A., Intrigliolo, F., Pompili, L., Nisini, L., Mocali, S., Torrisi, B. 2004. Effect of long term addition of composts and poultry manure on soil quality of citrus orchards in Southern Italy. Biol. Fertil. Soils 40, 206-210.

Cancela da Fonseca, J.P., Sarkar, S., 1996. On the evaluation of spatial diversity of soil microarthropod communities. Eur. J. Soil Biol. 32, 131-140.

Ciavatta, C., Govi, M., Vittori Antisari, L., Sequi, P., 1990. Characterization of humified compounds by extraction and fractionation on solid polyvynilpyrrolidone. J. Chromatogr. 509, 141-146.

Ciavatta, C., Govi, M., 1993. Use of insoluble polyvinylpyrrolidone and isoelectric focusing in the study of humic substances in soils and organic wastes. J. Chromatogr. 643, 261-270.

Cormack, W.F., Shepherds, M., Wilson, D.W., 2003. Legume species and management for stockless organic farming. Biol. Agric. Hortic. 21 (4), 383-398.

Cortet, J., Ronce, D., Poinsot-Balaguer, N., Beaufreton, C., Chabert, A., Viaux, P., Cancela de Fonseca, J.P., 2002. Impacts of different agricultural practices on 
the biodiversity of microarthropod communities in arable crop systems. Eur. J. Soil Biol. 38, 239-244.

Daniell, T.J., Husband, R., Fitter, A.H., Young, J.P.W., 2001. Molecular diversity of arbuscular mycorrhizal fungi colonising arable crops. FEMS Microbiol. Ecol. 36, 203-209.

De Goede, R.G.M., Brussaard, L., 2001. Soil zoology: an indispensable component of integrated ecosystem studies. Eur. J. Soil Biol. 38, 1-6.

Dell'Abate, M.T., Benedetti, A., Trinchera, A., Dazzi, C., 2002. Humic substances along the profile of two Typic Haploxerert. Geoderma 107, 281-296.

De Nobili, M., Ciavatta, C., Sequi, P., 1989. La valutazione del grado di maturazione della sostanza organica del compost mediante la determinazione di parametri dell'umificazione e la elettrofocalizzazione. In: International Symposium on Compost Production and Use. S. Michele all'Adige, pp. 328-342.

Dommergues, Y., 1960. La notion de coefficient de minéralisation du carbone dans les sols. Agron. Trop. XV (1), 54-60.

Doran, J.W., Parkin, S., 1994. Defining and assessing soil quality. In: Doran, J.W. Coleman, D.C., Bezdicek, D.F., Stewart, B.A. (Eds.), Defining Soil Quality for a Sustainable Environment, vol. 35. SSSA Special publication, pp. 3-21.

Drinkwater, L.E., Wagoner, P., Sarrantonio, M., 1998. Legume-based cropping systems have reduced carbon and nitrogen losses. Nature 396, 262-265.

Ferraro, D.O., Ghersa, C.M., 2007. Exploring the natural and human-induced effects on the assemblage of soil microarthropods communities in Argentina. Eur. J. Soil Biol. 109, 109-117.

Fließbach, A., Mäder, P., 2000. Microbial biomass and size-density fractions differ between soils of organic and conventional agricultural systems. Soil Biol. Biochem. 32, 757-768.

Franca, S.C., Gomes-da-Costa, S.M., Silveira, A.P.D., 2007. Microbial activity and arbuscular mycorrhizal fungal diversity in conventional and organic citrus orchards. Biol. Agric. Hortic. 25, 91-102.

Gardi, C., Tommaselli, M., Parisi, V., Petraglia, A., Santini, C., 2002. Soil quality indicators and biodiversity in northern Italian permanent grasslands. Eur. J. Soil Biol. 38, 103-110.

Gerdemann, J.W., Nicolson, T.H., 1963. Spores of endomycorrhizal Endogone species extracted from soil by wet sieving and decanting. Trans. Br. Myc. Soc. 46, 235244

Gerdemann, J.W., Trappe, J.M., 1974. The Endogonales in the Pacific Northwest. Mycol. Memoir 5, 1-76.

Giovannetti, M., 1985. Seasonal variations of vesicular-arbuscular mycorrhizas and endogonaceous spores in a maritime sand dune. Trans. Br. Mycol. Soc. 84, 679684

Giovannetti, M., Mosse, B., 1980. An evaluation of techniques for measuring vesicular arbuscular mycorrhizal infection in roots. New Phytol. 84, 489-500.

Giovannetti, M., Gianinazzi-Pearson, V., 1994. Biodiversity in arbuscular mycorrhizal fungi. Mycol. Res. 98, 705-715.

Govi, M., Ciavatta, C., Gessa, C., 1994. Evaluation of the stability of the organic matter in slurries, sludges and composts using humification parameters and isoelectric focusing. In: Senesi, S., Miano, T.M. (Eds.), Humic Substances in the Global Environment and Implications on Human Health. Elsevier Science, pp. 1311-1316.

Happerly, P., Douds, D., Seidel, R., 2006. The Rodale Institute Farming Systems trial 1981 to 2005: long term analysis of organic and conventional maize and soybean cropping systems. Can. J. Plant Sci. 1, 15-21.

Havlin, J.L., Kissel, D.E., Maddux, L.D., Classen, M.M., Long, J.H., 1990. Crop rotation and tillage effects on soil organic carbon and nitrogen. Soil Sci. Soc. Am. J. 54, $448-452$.

Helgason, T., Daniell, T.J., Husband, R., Fitter, A.H., Young, J.P.W., 1998. Ploughing up the wood-wide web? Nature 394, 431.

Herrick, J.E., Wander, M.M., 1997. Relationship between soil organic carbon and soil quality in cropped and rangeland soils: the importance of distribution composition and biological activity. In: Lal, R., Kimble, J.M., Stewart, B.A. (Eds.), Soil Processes and the Carbon Cycle. CRC Press, pp. 405-425

Jansa, J., Mozafar, A., Anken, T., Ruh, R., Sanders, I.R., Frossard, E., 2002. Diversity and structure of AMF communities as affected by tillage in a temperate soil. Mycorrhiza 12, 225-234.

Johnson, J.M.F., Allmaras, R.R., Reicosky, D.C., 2006. Estimating source carbon from crop residues roots and rhizodeposits using the national grain-yield database. Agron. J. 98, 622-636.

Johnson, N.C., Pfleger, F.L., 1992. Vesicular-arbuscular mycorrhizae and cultural stresses. In: Bethlenfalvay, G.J., Linderman, R.G. (Eds.), Mycorrhizae in Sustainable Agriculture, vol. 1. ASA, Madison, pp. 71-99.

Köpke, U., 2006. Foreword. In: Raupp, J., Pekrun, C., Oltmanns, M., Köpke, U. (Eds.), Long-term Field Experiments in Organic Farming. ISOFAR Scientific Series, Verlag, Berlin.

Isermeyer, H., 1952. Estimation of soil respiration in closed jars. In: Alef, K., Nannipieri, P. (Eds.), Method in Applied Soil Microbiology and Biochemistry. Academic Press, London, pp. 214-216.

Larson, W.E., Clapp, C.E., Pierre, W.H., Morachan, Y.B., 1972. Effects of increasing amounts of organic residues on continuous corn: II. Organic carbon nitrogen phosphorus and sulphur. Agron. J. 64, 204-208.

Lindberg, N., Bengtsson, J., 2005. Population responses of oribatid mites and collembolans after drought. Appl. Soil Ecol. 28, 163-174.

Lugato, E., Paustian, K., Giardini, L., 2006. Modelling soil organic carbon dynamics in two long-term experiments of north-eastern Italy. Agric. Ecosyst. Environ. 120, 423-432.

Mäder, P., Fließbach, A., Dubois, D., Gunst, L., Fried, P., Niggli, U., 2002. Soil fertility and biodiversity in organic farming. Science 296, 1694-1697.
Mäder, P., Fließbach, A., Dubois, D., Gunst, L., Oberholzer, H., 2003. Soil organic matter and biological soil quality indicators after 21 years of organic and conventional farming. Agric. Ecosyst. Environ. 118, 273-284.

Mahunka, S., Paoletti, M.G., 1984. Oribatid mites and other mites (Tarsonemidae, Anoetidae, Acaridae) from woods and farm monocultivated with corn in the low laying plain (Veneto and Friuli, N-E Italy). Redia LXVII, 93-128.

Melero, S., Riuz Porrai, J.C., Herencia, J.F., Madejon, E., 2006. Chemical and biochemical properties in a silty loam soil under conventional and organic management. Soil Tillage Res. 90, 162-170.

Miller, R.M., Jastrow, J.D., 2000. Mycorrhizal fungi influence soil structure. In: Kapulnik, Y., Douds, D.D. (Eds.), Arbuscular Mycorrhizas: Physiology and Function. Kluwer Academic Publishers, Dordrecht, pp. 3-18.

Mueller, P., Creamer, N., Barbercheck, M., Raczkowski, C., Bell, M., Brownie, C., Collins, A., Fager, K., Hu, S., Jackson, L., Koenning, S., Kuminoff, N., Linker, M., Louws, F., Mellage, S., Monks, D., Orr, D., Seem, J., Tu, C., Wagger, M., Walters, R., Wossink, A., Zhang, W., 2006. Long-term large scale systems research directed toward agricultural sustainability. In: Raupp, J., Pekrun, C., Oltmanns, M., Köpke, U. (Eds.), Long-term Field Experiments in Organic Farming. ISOFAR Scientific Series, Verlag, Berlin, pp. 79-98.

Oehl, F., Sieverding, E., Ineichen, K., Mäder, P., Boller, T., Wiemken, A., 2003. Impact of land use intensity on the species diversity of arbuscular mycorrhizal fungi in agroecosystems of Central Europe. Appl. Environ. Microbiol. 69, 2816-2824.

Osler, G.H.R., Murphy, D.V., 2005. Oribatid mite species richness and soil organic matter fractions in agricultural and native vegetation soil in Western Australia. Appl. Soil Ecol. 29, 93-98.

Parisi, V., 2001. La qualità biologica del suolo. Un metodo basato sui microarthropodi. Acta Naturalia de l'Ateneo Parmense 37, 97-106.

Parisi, V., Menta, C., Gardi, C., Jacomini, C., Mozzanica, E., 2005. Microarthropod communities as a tool to assess soil quality and biodiversity: a new approach in Italy. Agric. Ecosyst. Environ. 105, 323-333.

Park, J., Seaton, R.A.F., 1996. Integrative research and sustainable agriculture. Agric. Syst. 50, 81-100.

Paustian, K., Parton, W.J., Persson, J., 1992. Modelling soil organic matter in organic amended and nitrogen-fertilised long-term plots. Soil Sci. Soc. Am. J. 56, 476488.

Pell, M., Stenstrom, J., Granhall, U., 2005. Soil respiration. In: Bloem, J., Hopkins, D.W., Benedetti, A. (Eds.), Microbiological Methods for Assessing Soil Quality. CABI Publishing, pp. 117-126.

Phillips, J.M., Hayman, D.S., 1970. Improved procedures for clearing roots and staining parasitic and vesicular-arbuscular mycorrhizal fungi for rapid assessment of infection. Trans. Br. Mycol. Soc. 55, 158-160.

Pimentel, D., Hepperly, P., Hanson, J., Douds, D., Seidel, R., 2005. Environmental energetic and economic comparison of organic and conventional farming systems. BioScience 55, 573-581.

Porter, P., Allan, D., Crookstone, K., Harbur, M., Olson, K., Wyse, D., 2006. Overview of the University of Minnesota variable input crop management systems (VICMS) trial. In: Raupp, J., Pekrun, C., Oltmanns, M., Köpke, U. (Eds.), Long-term Field Experiments in Organic Farming. ISOFAR Scientific Series, Verlag, Berlin, pp. 99-116.

Rasmussen, P.E., Collins, H.P., 1991. Long-term impacts of tillage fertilizer and crop residue on soil organic matter in temperate semi-arid regions. Adv. Agron. 45, 93-134.

Reganold, J.P., Palmer, A., Lockhardt, J.C., Macgregor, A.N., 1993. Soil quality and financial performance of biodynamic and conventional farms in New Zealand. Science 260, 344-349.

Rodriguez-Echeverrìa, S., Freitas, H., 2006. Diversity of AMF associated with Ammophila arenaria ssp. arundinacea in Portuguese sand dunes. Mycorrhiza 16, 543552.

Sabatini, M.A., Rebecchi, L., Cappi, C., Bertolani, R., Fratello, B., 1997. Long term effects of three different continuous tillage practices on Collembola populations. Pedobiologia 41, 185-193.

Sayre, P., 2005. Organic farming combats global warming: big time. BioScience 7, 573-582.

Schenck, N.C., Perez, Y., 1990. Manual for the Identification of VA Mycorrhizal Fungi, 3rd ed. Synergistic, Gainesville.

Schloter, M., Munch, J.C., Tittarelli, F., 2005. Managing soil quality. In: Bloem, J. Hopkins, D.W., Benedetti, A. (Eds.), Microbiological Methods for Assessing Soil Quality. CABI Publishing, pp. 50-70.

Schrader, S., Kiehne, J., Anderson, T., Paulsen, H., 2006. Development of Colembolans after conversion towards organic farming. In: Atkinson, C., Younie, D. (Eds.), What Will Organic Farming Deliver? Aspects of Applied Biology. vol. 79. AAB Office Warwick, UK, pp. 181-184.

Siepel, H., 1996. Biodiversity of soil microarthropods: the filtering of species. Biodiversity Conserv. 5, 251-260.

Smith, S.E., Read, D.J., 1997. Mycorrhizal Symbiosis. Academic Press, San Diego, 605 pp.

Solbrig, O.T., 1992. Biodiversity: an introduction. In: Solbrig O.T., van Emden, H.M., van Oordt, P.G.W.J. (Eds.), Biodiversity and Global Change. IUBS, Paris, pp. 1320.

SPSS Inc. 1994. SPSS for Windows 6.1. Chicago, IL.

Springer, U., Klee, J., 1954. Prüfung der Leistungsfähigkeit von einigen wichtigeren Verfahren zur Bestimmung des Kohlemstoffs mittels Chromschwefelsäure sowie Vorschlag einer neuen Schnellmethode. Z. Pflanzenernähr. Dang. Bodenk 64, p. 1 .

Tabaglio, V., Gavazzi, C., Menta, C., 2009. Physical-chemical indicators and microarthropods communities as influenced by no-till, conventional tillage and 
nitrose fertilization after four years of continuous maize. Soil Tillage Res. 105 135-142.

Turrini, A., Avio, L., Bedini, S., Giovannetti, M., 2008. In situ collection of endangered arbuscular mycorrhizal fungi in a Mediterranean UNESCO biosphere reserve. Biodivers. Conserv. 17, 643-657.

USDA-NRCS, 1996. Soil Survey Laboratory Methods Manual. Soil Survey Inv Rep N 42, version 3.0. USDA, Washington, DC.
Vance, E.D., Brookes, P.C., Jenkinson, D.S., 1987. An extraction method for measuring microbial biomass C. Soil Biol. Biochem. 19, 703-707.

Van Diepeningen, A.D., De Vos, O.J., Korthals, G.W., Van Bruggen, A.H.C., 2006 Effects of organic versus conventional management on chemical and biological parameters in agricultural soils. Appl. Soil Ecol. 31, 120-135.

Zhu, Y.G., Miller, R.M., 2003. Carbon cycling by arbuscular mycorrhizal fungi in soilplant systems. Trends Plant Sci. 8, 407-409. 